\title{
In a New Light: Early African American Photography
}

\section{Tanya Sheehan}
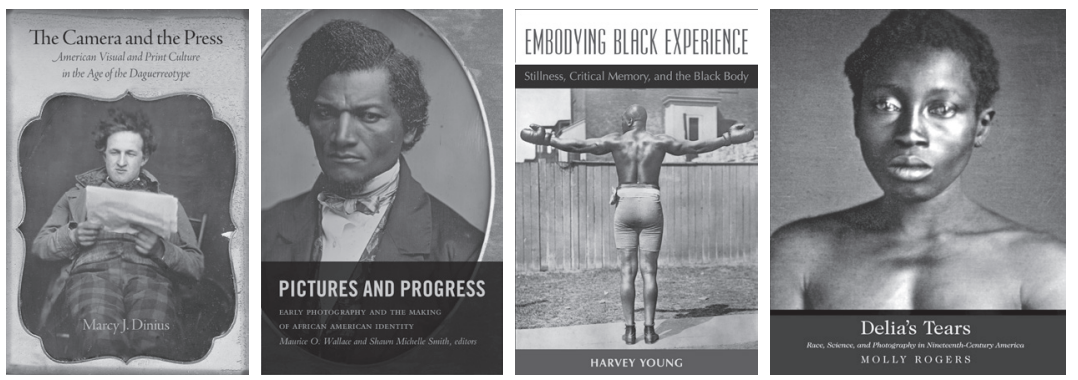

THE CAMERA AND THE PRESS: American Visual and Print Culture in the Age of the Daguerreotype. By Marcy J. Dinius. Philadelphia: University of Pennsylvania Press. 2012.

PICTURES AND PROGRESS: Early Photography and the Making of African American Identity. Edited by Maurice O. Wallace and Shawn Michelle Smith. Durham: Duke University Press. 2012.

EMBODYING BLACK EXPERIENCE: Stillness, Critical Memory, and the Black Body. By Harvey Young. Ann Arbor: University of Michigan Press. 2010. DELIA'S TEARS: Race, Science, and Photography in Nineteenth-Century America. New Haven: Yale University Press. 2010.

In 2000, art historian, curator, and artist Deborah Willis presented Reflections in Black, the first major history of photography in the United States to foreground early African American photography. In the three years that the exhibition toured 


\section{Tanya Sheehan}

the country, and in the decade that its catalogue has been read avidly by students, historians, and practitioners of photography, Reflections in Black has exercised a powerful influence on how we think about photographic self-representation within the African American community. Willis taught us how to look for and at images that did not grossly caricature black bodies but instead "celebrated the achievements" of black subjects and "conveyed a sense of self and self-worth" (Willis, xvii). The placement of cameras in black hands, she argued, made such counter-representation possible; writing a different history of African American life and culture therefore depended on rediscovering the first black photographers. Scholars today remain indebted to the work of Reflections in Black as they develop new critical approaches to the study of early African American photography. The four books under review here, all published between 2010 and 2012, exemplify some of those approaches. Together they shed new light on photographic practices in the nineteenth and early twentieth centuries not only by attending to the experiences and desires of African American photographers, photographic subjects, and viewers (both then and now), but also by reflecting deeply on the complex interactions between the past and present, history and theory, word and image.

The most recent of these publications, Pictures and Progress, builds upon Willis's work by "recover[ing] the various ways in which nineteenth- and early twentieth-century African Americans viewed, conceptualized, and most importantly used the new technology of photography to chart and change and enjoy new social positions and political identities." This volume of essays, edited by U.S. cultural historians Maurice O. Wallace and Shawn Michelle Smith defines the central problem it seeks to address as follows: "we know more about the imagery of racism than we do about what African American men and women did when they took photography into their own hands" (4). For Wallace and Smith, the act of taking the medium into one's hands is symbolic of agency and should be understood in both literal and figurative terms. Adding this figurative dimension allows the editors to significantly expand upon the collection of early black photographers assembled in Reflections in Black. Augustus Washington, Thomas Askew, A. P. Bedou, and J. P. Ball — photographers researched extensively by Willis and now featured in survey histories of American photography-are represented in four short essays by Smith that she calls "critical snapshots." The eleven main essays in the volume examine other figures as "important theorists and practitioners of photography," specifically "prominent African American intellectuals, authors, orators, and activists" who "may never have picked up cameras themselves." As the contributors to Pictures and Progress deftly argue, Frederick Douglass, Sojourner Truth, Ida B. Wells, Paul Laurence Dunbar, and W. E. B. Du Bois all "practiced" photography; that is to say, "they put photographs to striking use in their varied quests for social and political justice, plumbing and expanding the political power of the photograph" (4).

Frederick Douglass plays a central role in Pictures and Progress, inspiring the volume's title and serving as the focus of its opening essays by Laura Wexler 
and Ginger Hill. The former slave turned outspoken abolitionist had much to say about photography in the two decades or so after the public announcement of its invention in 1839. In a series of lectures devoted to the subject of "pictures," Wallace and Smith remind us, Douglass promoted "picture making" as a skill that distinguished men from animals and that could serve as the "primary catalyst for social change" (6). The key to such change was "making ourselves and others objects of 'observation and contemplation"' (7). In Douglass's view, members of the African American community, on the eve of emancipation, had to first picture themselves in order to achieve social progress. Photography enabled such work by being accessible to "ordinary people" (6). That the medium produced enduring records of the past, prolonging the "presence of absent subjects," further endowed it with the capacity to "shape the future" (8).

Both Wexler and Hill make these general readings of Douglass's views on photography specific to historical texts and contexts while presenting the celebrated black orator and writer as one of the nation's first theorists of the photographic image. Wexler accomplishes this by comparing different versions of his lectures on pictures, noting the dialogue between them and Abraham Lincoln's conception of the American Union, and placing Douglass in conversation with Roland Barthes. Although the former slave and the modern French (post)structuralist may seem an unlikely pair, Wexler observes that they both associated photography with social death - but with an important difference. While in Camera Lucida (1981) Barthes described the experience of sitting before the camera as a living person's confrontation with his own death, Douglass imagined the slave as "a social corpse ... [that] is animated through the photograph" (30-31). According to Wexler, Douglass thus challenged Barthes's theory of photography avant la lettre, providing us with a conception of photography as raising the dead-or bringing freedom, agency, and a new life to the enslaved. Ginger Hill extends this reframing of Douglass as visual theorist by arguing that his ideas about pictures constituted "a theory about systems of representations . . . broadened into nothing less than a theory of subjectivity ..." (70). He advocated, moreover, the necessity of "critical looking" - that is, questioning "appearance, experience, and truth" and reflecting on how we see ourselves and others. On these grounds, Hill finds a strong similarity between Douglass's critical position and the ideas developed by French philosopher Maurice Merleau-Ponty in the mid-twentieth century (44).

One can see why turning to twentieth-century critical thought would be attractive to these contributors to Pictures and Progress. After all, it positions Douglass's ideas as conversant with two of the most celebrated theoreticians of the photographic image, thereby demonstrating to writers on photography outside of African American studies why Douglass should be taken seriously. And yet it remains concerning that scholarship on early black photography in the twenty-first century finds it necessary to legitimize its objects of study in this way, for doing so reinforces the authority of the canonical (white, masculinist) discourse from which those objects have been long excluded. Recent critiques of 
Barthes's text by Margaret Olin (2002), Shawn Smith (2007), and Carol Mavor (2009) have managed to avoid this potential problem by examining how modern photographic theory has re-presented early African American photography. Appearing together in a 2009 anthology edited by Geoffrey Batchen, essays by these authors rely on close textual analysis or personal reflection to challenge the troubling representations of blackness in Camera Lucida. In articulating its notion of the punctum through an African American studio portrait made by Harlem photographer James Van Der Zee in 1926, they argue, this foundational text reveals nothing about black portraiture yet much about the psycho-sexual struggles, false memories, and paternalist racism of its author. What we see in his reproduction of the Van Der Zee photograph is thus precisely what Barthes wanted us to see: Barthes himself.

The Camera and the Press (2012) by Marcy Dinius shares the goal of Pictures and Progress to frame early African American photography as both a literary and visual practice, but it does so by firmly grounding its arguments in the antebellum period. The book specifically explores how Americans first encountered daguerreotypes, arguably the first photographic process, through the medium of print. These writings on daguerreotypy in newspapers, trade publications, and popular literature did more than introduce readers to a new visual medium; they used the medium "to advance a national self-image based on principles of progress, industry, and democracy" (4). As several chapters in The Camera and the Press explain, that self-image was fashioned in relation to arguments about race, slavery, and its abolition on the eve of the Civil War.

Dinius's discussion of African Americans and photography begins in chapter 4 with an innovative rereading of Harriet Beecher Stowe's Uncle Tom's Cabin (1852), one that explores the political consequences of the novel's references to daguerreotypy. There she brilliantly unpacks a moment in the text when the character of Uncle Tom is described for readers, or "daguerreotyped" (as Stowe put it). That the text invokes photography explicitly and figuratively at this moment is significant, Dinius argues, because it acknowledges the medium's perceived mechanical objectivity as a useful political tool. By relying on period writing on daguerreotypy's representational authority, in other words, Stowe provided her readers with "what would have been understood as a detailed, lifelike, and accurate representation of both the experience of slavery and the slave's identity as a man" (128). They therefore would have been encouraged to see Tom "as a real person rather than a fictional character," a subject with whom they could feel sympathy, and to view the novel itself as more than "mere fiction" (132). Dinius takes this argument further, reminding us that the very materiality of the daguerreotype - specifically, viewers' ability to see themselves in its mirror-like surface - reinforced the "powerful affective attachment" that Stowe sought to forge between Tom and her readers. Indeed, critical readings of the daguerreotype's tactile and reflective qualities appear throughout The Camera and the Press, demonstrating the book's laudable ability to bring material culture into the conversation. 
In chapter 5 Dinius turns to the work of African American daguerreotypist Augustus Washington, who set up a successful portrait studio in Hartford in the late 1840s before emigrating to Liberia in 1853. Many of the intriguing details of Washington's life are known to scholars today from Reflections in Black as well as from a major exhibition of his work curated by Ann Shumard, which was shown at the Smithsonian's National Portrait Gallery, the International Center of Photography (ICP), and the Connecticut Historical Society in 1999-2000. Shawn Smith also devotes one of her "critical snapshots" in Pictures and Progress to Washington, summarizing his biography and reflecting on his well-known daguerreotype of radical abolitionist John Brown from 1846 or 1847 . What captivates Smith is not only the singularity of Washington's career in African American history and the historiography of photography, but the epistemological problem that his portrait of John Brown presents modern viewers. Simply put, we cannot view the daguerreotype without thinking about the raid on Harper's Ferry that Brown led some thirteen years later. While Smith offers us a theoretically informed reflection on what it means to read (or refuse to read) the historical record back into a photograph, The Camera and the Press tells a new story about Washington's writings and images that is based on historically specific theories of race and representation. The book presents his search for a "more congenial home" for African Americans in Liberia as linked to "the expansion of the American empire, intensifying debates about slavery, and the 1850 passage of the Fugitive Slave Law, as well as his growing renown and financial success as a daguerreotypist" (156).

In Hartford, Washington worked to bring daguerreotypy to a broad public, envisioning daguerreotype portraiture both as a professional service he could provide and a political right that should be available to every American. While this idea may remind us of Frederick Douglass's faith in the democratizing power of photography, we also hear echoes of Stowe in Washington's writings on Liberia, which bring the so-called mechanical objectivity of the daguerreotype into the service of radical politics. Through his exchanges with the American Colonization Society and the American press, which took the form of letters as well as portraits of Liberian officials, Washington sought to "daguerreotype" the conditions in the developing nation. According to Dinius, his aims in doing so were twofold: to provide an "accurate" view of Liberia that would disseminate knowledge of the work remaining to be done there; and to encourage a widespread recognition of the "reality" of the new, all-black government. Here, and indeed throughout The Camera and the Press, Dinius assumes that the cultural belief in photography's authority in antebellum America was both produced and reproduced by such aims.

That Frederick Douglass also figures centrally in The Camera and the Press reiterates the importance of recovering his ideas about photography and the many ways in which those ideas can be mobilized by modern scholars. Like Wallace and Smith, Dinius claims that the "connection between Douglass's political philosophy and daguerreotypy is even more substantial than ... previous scholar- 
ship on Douglass and photography suggests." Chapter 6 of her book, however, does much more than mine Douglass's lectures on pictures for their ideas about "personhood, race relations, and material and moral progress" (194). We learn, for example, that his work as a newspaper editor brought Douglass into relation with writing on daguerreotypy; he published articles on black photographers such as Washington and J. P. Ball; and, like Stowe, he used daguerreotypy as a political metaphor in his essays and fiction. One fascinating example of this last practice is the analogy Douglass once made between a racially black face and a daguerreian plate. Inviting us to recall the material qualities of the daguerreotype, Dinius explains that the silver, mirror-like surface of the daguerreotype reverses the dark and light tones of the image when viewed at certain angles. Douglass exploited this technical fact when he proposed: "looking at a black man, the white man sees not himself but his dark opposite," or his daguerreian other. The white man's "honor and veracity" will then begin to "invert," and he will treat the black man poorly (200). Dinius later argues that "the unique characteristics of the daguerreian medium" account in part for Douglass's particular interest in it; for it was in those characteristics, different from those of any other form of photography, that Douglass located "the message of democracy" (210).

This line of argument about medium specificity extends to Douglass's own daguerreotyped portraits, six of which are extant and reproduced together for the first time in The Camera and the Press. Not only does Dinius reflect on the modern experience of holding a daguerreotype of Douglass in one's hands, she also invites us to compare the modes of self-representation apparent across his portraits, noting consistencies and differences in pose, dress, hairstyle, lighting, and so on. For their part, Laura Wexler and Ginger Hill offer an expanded view of the numerous photographs that were made of the former slave between the 1840 s and 1895 . Wexler, for instance, locates in these studio portraits Douglass's attempt to insert himself into the nation's gallery of illustrious Americans as a "living image" of progress and a representative example of his own theories. Hill, on the other hand, sees evidence in these pictures of their sitter's "self-mastery" and "free status," but detects irony in their repetition and accumulation (48). It is as if the constant photographic (re)production of Douglass as "citizen-subject" suggested that such standing was tenuous at best (50).

While much is to be gained from studying the development of photography over the whole of the nineteenth century, Pictures and Progress could have done more to construct its arguments around particular photographic processes, as Dinius does with the daguerreotype. Indeed, the essays that this reader found most satisfying were those in which different media of representation were imagined to have different relations to the "real"; these relations, in turn, shaped the meanings of the images they (re)produced. In Augusta Rohrbach's contribution to the volume, for instance, we gain a richer understanding of how the celebrated African American female abolitionist, Sojourner Truth, fashioned herself through print and visual media by working both with and against their specific conventions of self-representation. In addition to revisiting Truth's well-known public speeches 


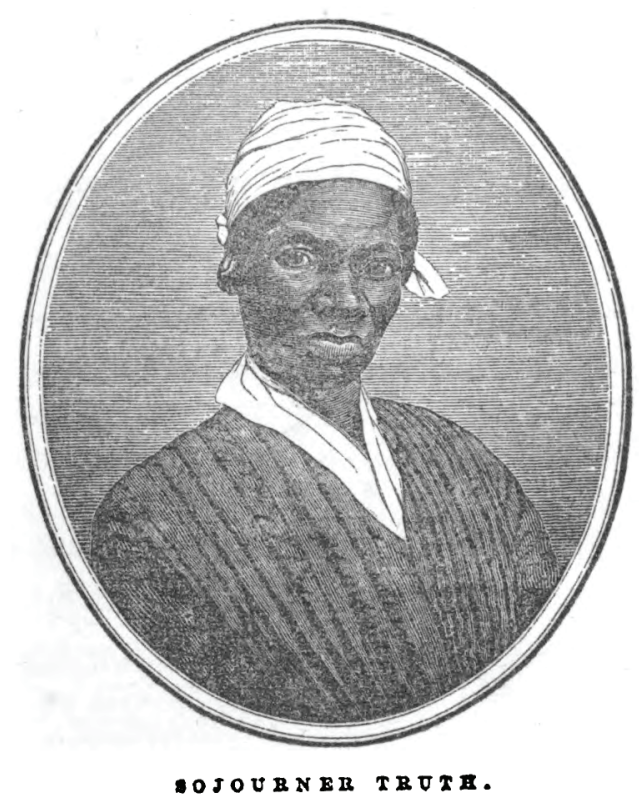

Figure 1: Engraved frontispiece from Sojourner Truth, Narrative of Sojourner Truth: a northern slave, emancipated from bodily servitude by the state of New York, in 1828 (Boston: Printed for the author, 1850).

on selfhood and the carte-de-visite portraits of her likeness that she sold in 1864, Rohrbach takes a close look at an engraved frontispiece of Truth that appeared in editions of the Narrative of Sojourner Truth (1850) (Figure 1). Here Rohrbach poses an important question about mediation: Why does the text refer to this portrait in photographic terms (as a "picture taken") when it may not have been made from an actual photograph of Truth? One might challenge her assumption that a photographic source for the engraving doesn't exist; indeed, the format and presentation of the body suggest otherwise. But Rohrbach is right to not let this matter detract from the text's insistence on a photographic reference and its significance for Truth. For here we see "the image's status"- -its apparent basis in objectivity and truth - "inserted as testimony" into a narrative that is filled with representations of Truth by Frances Dana Gage, Harriet Beecher Stowe, and others (93). While generally sympathetic with Truth's activism, such writing still relied on racial and gender stereotype to depict its subject. The "photographic" image, Rohrbach proffers, may have been an attempt to counter such stereotype - to present a different, and possibly more "accurate," construction of self. Another essay in Pictures and Progress by P. Gabrielle Foreman, first published in the journal American Literary History in 2002, nicely complicates this discussion of photography, accuracy, and self-representation. The subjects of Foreman's essay are the strategies of self-representation deployed by African American women 


\section{Tanya Sheehan}

who famously and temporarily passed as "white," including Ellen Craft and Louisa Piquet. In the matter of defining racial identity in antebellum America, she argues, images of "mulatta" and "octoroon" women "provided a proving ground" for photography, "yet threatened to disrupt the very assumptions on which its authority was based" (154). So Foreman concludes, "there is still much more to be said about [photography's] production and disruption of racial (and gendered) 'truth"” (157).

The other contributors to Pictures and Progress, in fact, have much more to say about this issue. Ray Sapirstein considers the photographically illustrated volumes of Paul Laurence Dunbar's dialect poetry that were published between 1896 and 1906. That the photographs were taken by the predominantly white faculty members of the Hampton Institute Camera Club presents an interesting problem for Sapirstein. He suggests, for instance, that the illustrations may be "more rhetorically black than the vast majority of images of African Americans made at the time," if we take into account Dunbar's influence on their production and the photographers' familiarity with the "nuances of black vernacular culture" at the Virginia institution dedicated to the education of southern blacks (187-88). At the same time Sapirstein wants to argue that the images made by the Camera Club "deliver no interior truth of African American character, despite their promise of an insider's access into African American life" (189). This claim seems to be confirmed readily by a typical illustration of Dunbar's dialect poems photographed by Leigh Richmond Miner (Figure 2). In the 1905 publication of "De Way T'ings Come," readers would have encountered a generic representation of a black woman and child in the rural American south - neither identified individuals with complex interiorities, nor embodiments of degrading stereotypes.

A similar ambivalence runs through Maurice Wallace's meditation on photographic fantasies of black masculinity during and after the Civil War. Focusing on the "popularity and proliferation of the black soldier portrait" in this period, Wallace wants to claim for photography "the genesis of African American manhood as a coherent category of civil identity and experience in the postbellum political imaginary" (247) — an important achievement, to be sure. And yet the staged photographs of Hubbard Pryor that he discusses, which depict their black subject before and after his enlistment in the Forty-fourth U.S. Colored Troops Infantry in 1864, display what Wallace describes as a "coerced agency" and "simulated contentment" (259) (Figure 3a/b). Although Wallace does not undertake such work in his essay, looking at other staged portraits of African Americans by the same Nashville portrait studio reveals just how astute his description may be. As seen in the 2006 ICP exhibition, "African American Vernacular Photography: Selections from the Daniel Cowin Collection," the Morse and Peaslee studio created another pair of before-and-after photographs around 1863. This pair caricatured a black boy's experience of emancipation; in the "before" picture, he faces the viewer with a stern expression, while in the "after" he boasts an exaggerated, toothy grin (see http://emuseum.icp.org; accession number 893.1990). The existence of this pair simultaneously complicates 


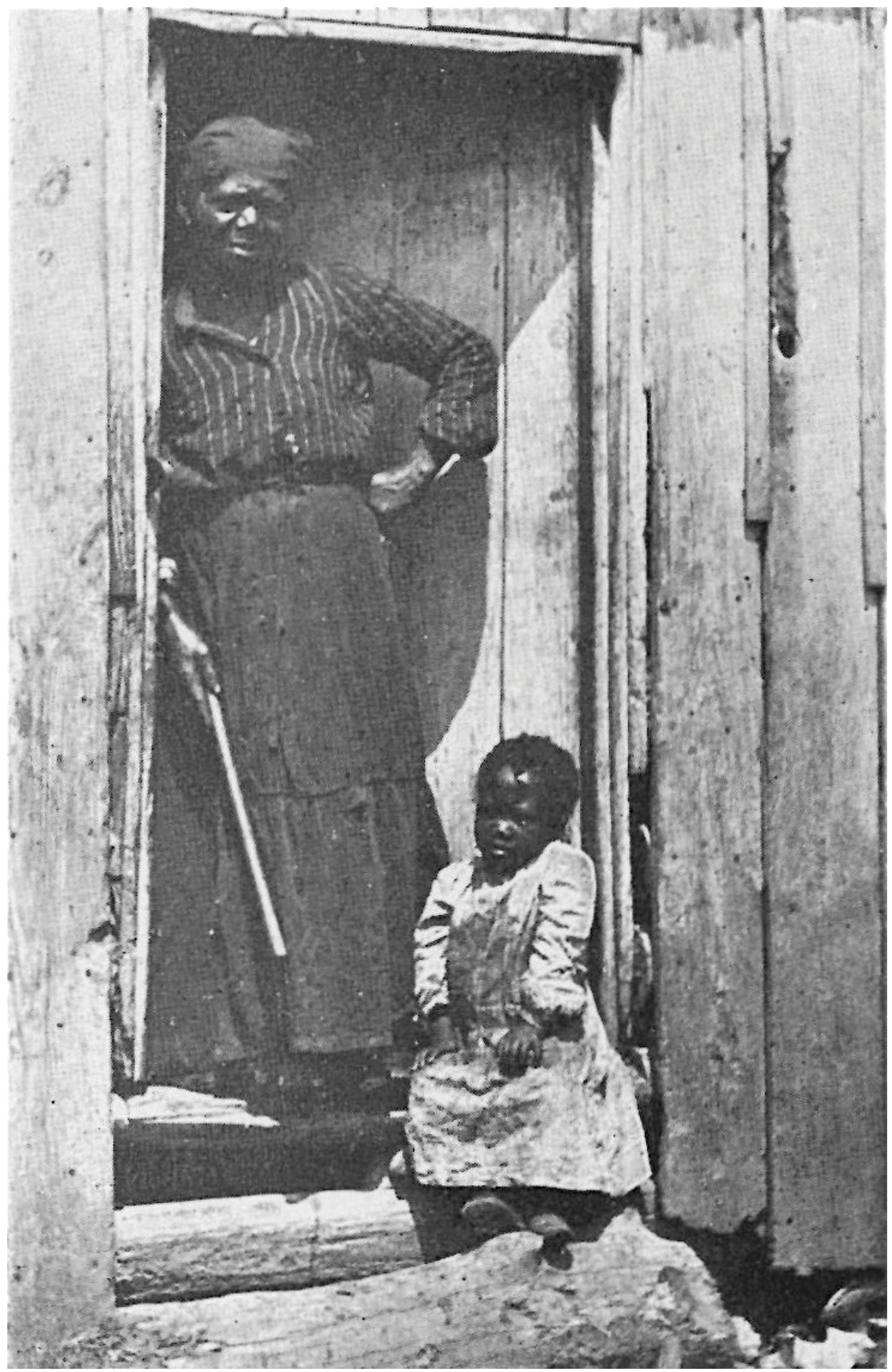

Figure 2: Photograph by Leigh Richmond Miner used to illustrate "De Way T'ings Come" in Paul Laurence Dunbar, Howdy Honey Howdy (Dodd, Mead and Co., 1905), n.p. 
16 Tanya Sheehan

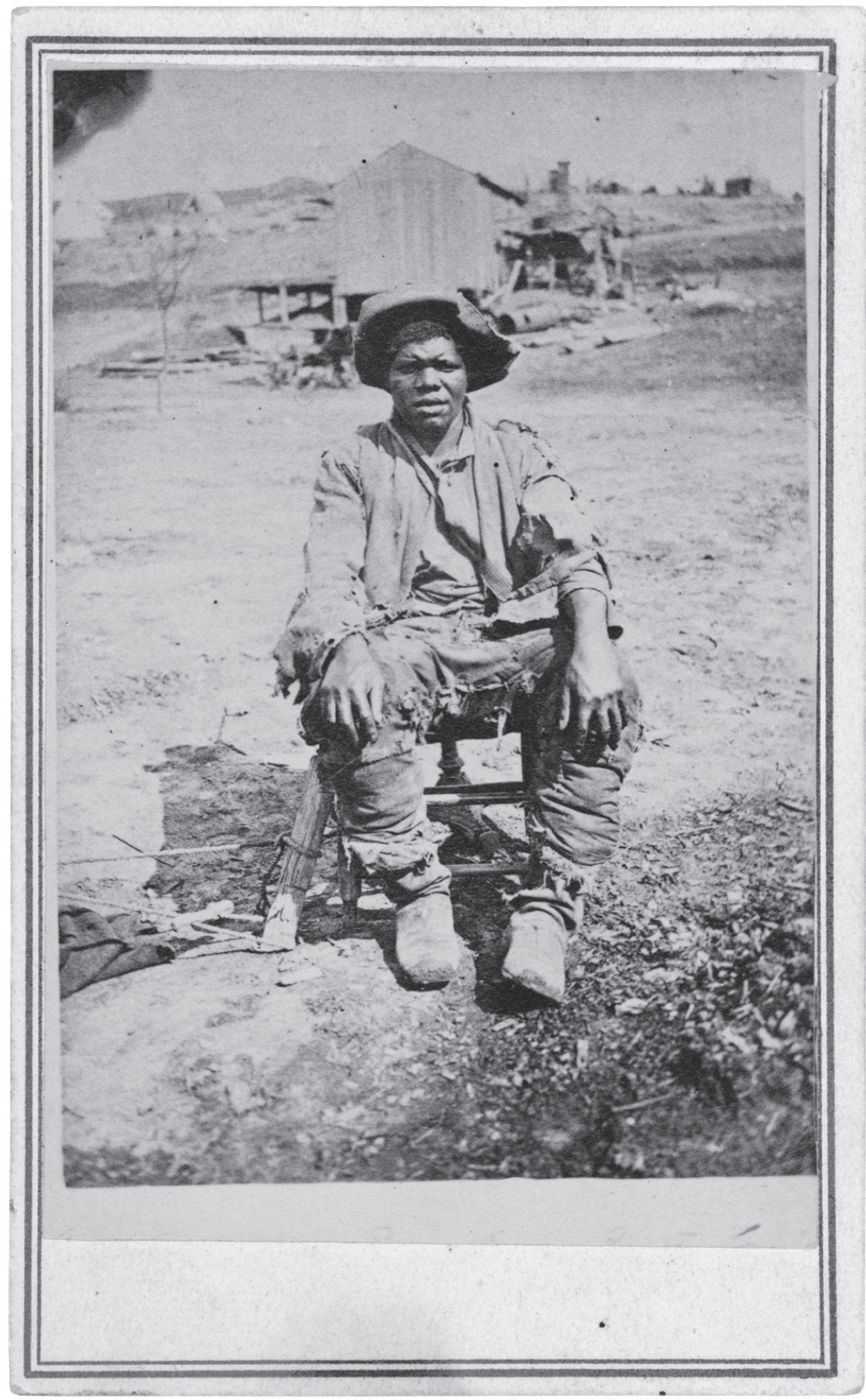

Figure 3a: Morse and Peaslee, Photograph of Private Hubbard Pryor before Enlistment in 44th U.S. Colored Troops, October 10, 1864, National Archives 849127. 


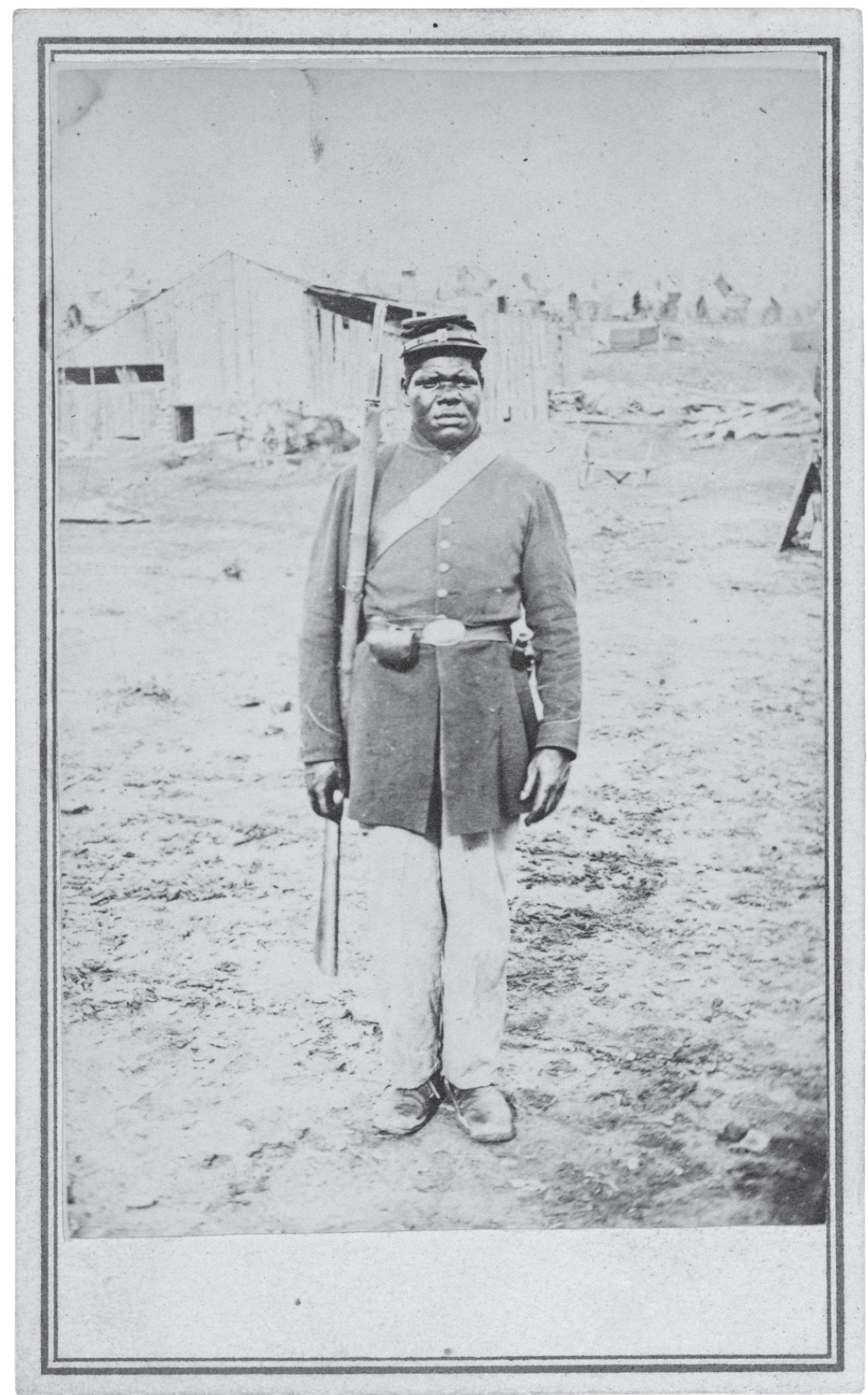

Figure 3b: Morse and Peaslee, Photograph of Private Hubbard Pryor after Enlistment in 44th U.S. Colored Troops, October 10, 1864, National Archives 849136. 
our understanding of the Hubbard photographs and their inclusion in a report on black recruitment submitted to the U.S. War Department in 1864. Perhaps they are not portraits at all. They could even be parodies of the very construction of black masculinity that Wallace attributes to photography at this historical moment.

An important concept that informs Wallace's analysis and several other essays in Pictures and Progress is that of the archive. Shawn Smith includes in the volume, for example, her much-reprinted essay on the photographs that W. E. B. Du Bois assembled for the American Negro Exhibit at the Paris Exposition of 1900. In her reading of these images, which consist primarily of frontal and profile views of bourgeois southern blacks, Smith "restores a key text to the visual archives of U.S. race relations." That is to say, "Du Bois's photographs contest the discourses and images of an imagined 'Negro criminality' that were evoked to legitimize the crime of lynching" in the United States at the turn of the century (274). Leigh Raiford extends this discussion of what constitutes an archive of African American representation in her essay on Ida B. Wells's antilynching campaigns of the late nineteenth and early twentieth centuries. These campaigns, Raiford tells us, relied on a variety of photographs: photographs of actual lynchings, including the now iconic images of black bodies hanging limply from trees surrounded by smiling white faces; professional studio portraits of Wells herself; and photographs of Wells with the widows and children of lynched men. Drawing upon Allan Sekula's influential essay, "The Body and the Archive" (1986), Raiford asks us to read these "repressive" and the "honorific" portraits of African Americans as interdependent, and as belonging to a collective "shadow archive" (300). An important implication of this proposal is an expansion of the genre scholars know as "lynching photography" to include a much broader range of vernacular images.

The final essay in the volume by Cheryl Finley returns to questions about the archive by reflecting on the construction, collection, and interpretation of early vernacular photographic albums. Here we find Finley addressing the term's more conventional sense - the archive as a collection of or repository for historical objects - and engaging with its challenges for contemporary viewers. In the specific case of African American photo albums, she asks, can we "salvage, restore, or re-create" their narratives when they "cease to be illegible" to a modern viewer? Further, "what are the risks of this kind of rescue work?" (331). Finley describes at length her experience of encountering a particular tintype album for the first time at an art auction in 1992: pondering its origins, carefully inspecting its materiality, and observing the poses, dress, and studio settings visible in the small photographs on iron. She admits to having created a narrative for the album's pictures that incorporated some of her own personal and family stories, bringing to mind Martha Langford's efforts to reanimate historical photographic albums through personal memories and feelings (Langford 2001). Finley further inserted herself into the album's story by purchasing the little archive for herself, wanting to rescue it (and its literally iron-clad subjects) from the auction block. 
Finley's questions about the methods and consequences of recreating historical narratives in the present have particular relevance to a photographic archive that has received enormous critical attention since its rediscovery in 1976: the daguerreotypes of slaves made by South Carolina studio photographer J. T. Zealy in 1850 at the request of the renowned Swiss scientist Louis Agassiz. Significantly, this series plays an important role in all four of the books considered here. Of these, Delia's Tears (2010) by Molly Rogers offers the most sustained engagement with the pictures, devoting nearly 400 pages to them. Previously, Rogers observes, some scholars have chosen to see Zealy's pictures as representative of racial types, as Agassiz himself hoped they would be; others have chosen to "acknowledge the 'humanity' of the people in the photographs" in an effort to "free" them from an objectifying, scientific gaze. Marcy Dinius's discussion of the daguerreotypes in her chapter on Frederick Douglass might be said to belong to the first camp. There the images serve an instrumental role in her reading of a profile portrait of Douglass as asserting his mixed race through the profile format, skin tone, hair, features, clothing, and so on. Rogers, however, sets out to write a story of "Delia, Jack, Renty, Drana, Jem, Alfred, and Fassena" that incorporates their perspectives, while remaining self-conscious about her own contributions to and power over that narrative. Rogers wants "to celebrate the dignity of human agency and self-determination in the face of adversity" through the daguerreotypes, "and to do so with historical accuracy" (xxiii). Claiming inspiration from the literature of Toni Morrison and drawing from her own experience as a creative writer, she locates in fiction a possible means to this historiographical ends. "Delia's story," Rogers offers, "could be written as a novel, her life dramatized through the medium of imagination" (xxiv). This could produce a "more complete narrative," but she admits that it may also take us away from "Delia herself" and "result in misrepresentation, another form of violation" (xxiv). With these methodological reservations, Delia's Tears takes the plunge, resulting in the most creative and thought-provoking interpretation of the Agassiz daguerreotypes published to date.

Addressing both an academic and general audience, much of the book recounts known bits of history: the production of the photographs in Zealy's studio, the ideas about race they were created to support (and refute) in the mid-nineteenth century, and their subsequent discovery at Harvard University's Peabody Museum. We are told of the conventions of early studio portraiture, the development of the American school of ethnology, and the connection between the two. We learn about the genesis of Agassiz's theory of polygenesis, which viewed the different races as separate species, its impact on scientific and popular circles in the United States, and efforts to challenge its claims from the African American community. The uniqueness of Rogers's approach thus stems not as much from this collection of data as from her recourse to imagination; she literally invents the perspectives of the people photographed, presenting them to us in short vignettes that introduce each chapter. These draw from the scant historical evidence we have about each subject as well as early photographic 
trade journals and slave narratives. Yet they stand in the book "unabashedly as works of fiction." Consider the following excerpt from the first vignette, which invents Delia's experience of the portrait studio:

She was not supposed to be there. Nothing in her life so far had prepared her for this. All those years of working, sweating, laboring in the fields and later in the forge, none of it had so much as hinted at this. Oh, she knew there were places, other places where everything looked and smelled different, where the air seemed lighter and the light less harsh-she knew these places existed, but she was never supposed to be in one. Perhaps she had even seen a photograph once, in the great house. But she herself was never supposed to have her picture made. This was no place for a slave.

This much she knew.

The vignette continues in the same vein, as we hear of the sun beating down on Delia's body through the studio skylight, her desire to move from the chair, her fear of repercussions for doing so, the apparently friendly dispossession of the photographer, the presence in the studio of the local "Doctor" (Robert Wilson Gibbes) who presided over the sitting, Delia's memory of meeting him for the first time and coming to this place, her struggle to hold still, the photographer's instruction that she bare her breasts for the camera, and her feeling of disappearing at the moment of exposure.

Delia knew, Delia remembered, Delia felt; Rogers conjures up these actions for us through her fiction, as promised. Yet I admit having experienced apprehension and discomfort when reading these lines for the first time in 2010. I was reacting then to the definitiveness with which they were asserted and the deliberateness of their placement in the mind of the lost subject we call "Delia." To be told what she thought about having her photograph taken, what the photographic experience meant to her, struck me as precisely the kind of violation of which Rogers had warned her readers. Her construction of Delia's subjectivity, moreover, struck me as relying on thinly veiled stereotype, drawn from nineteenth-century conceptions of racial others as confounded by and fearful of modern science and technologies - especially the photographic apparatus. This struck me as different from Finley's imaginative reading of the archive. Redeeming the vignettes in Delia's Tears for me, three years later, are the astute critical questions that led Rogers to create them in the first place, and her awareness of the problems inherent to her own methods. The book conducts a carefully monitored experiment, but remains fully at peace with the possibility of its failure. As Rogers put it, she set out "to mix things up a bit in the hope of making Delia a little more visible, a little more present in the eyes of others" (xxv). 
In Embodying Black Experience (2010), Harvey Young incorporates the Agassiz daguerreotypes into his own critical experiment operating at the intersection of performance studies and critical race theory. With chapters on Zealy's sitters, black boxing champions, contemporary performances of the "Hottentot Venus," and the spectacle of lynching, the book sets out to explore "moments of experiential overlap" in the African American community. According to Young, the experience of a slave who "stood still before [Zealy's] daguerreotype camera, echoes the experience of other black captives who stood still on the auction blocks and prefigures those of hundreds of thousands of black bodies who reenact moments of arrest and re-arrest in police precincts every year" (5). Young's conception of the black body as "an abstracted and imagined figure," the "target of a racializing projection," builds upon efforts to theorize blackness by Paul Gilroy, Stuart Hall, Kobena Mercer, E. Patrick Johnson, and others. In his engagement with early African American photography, Young draws from the work of Deborah Willis, bell hooks, Alan Trachtenberg, and Cherise Smith.

Chapter 2 of Embodying Black Experience places the Agassiz daguerreotypes in dialogue with other efforts to capture black bodies: specifically, portraits made in the 1920s by African American studio photographer Richard Roberts in Columbia, South Carolina, and Walker Evans's Depression-era documentary photography. Weaving together these three seemingly disparate sets of images, Young argues, is the idea that the black bodies in the photographs "actively perform stillness." Such stillness "resonate[d] with their daily, lived embodied experiences," in which they may have felt captive due to restrictions placed on their physical and social movement-restrictions that had their origin in the Middle Passage. Young also encourages us to see stillness as a kind of agency; for the act of standing still literally "enabled the creation of the photograph and, in turn, established a place for the captives within the historical archive" (29). Other aspects of the chapter seek a similar critical balance. Young articulates a faith in the modern scholar's ability to "access" the experiences of the sitters through close reading of the photographic record, for instance, insisting at one point that "to look at Alfred [one of Zealy's sitters] is to see a person . . . who consciously is enacting motionless" (44). But he also acknowledges Rogers's concern that access cannot always be assumed in the case of the Agassiz series. "When we look at the daguerreotype of Delia," Young asks, "are we really seeing Delia?" (34). Or are we looking at "the black body as imagined by Agassiz and imaged by Zealy" (49)?

As the chapter unfolds, Young precludes simple responses to these questions by reading the daguerreotypes as "reveal[ing] the convergence of the past, present, and future" (50). The pictures bring together the moments when the slaves stood still before Agassiz on the plantation, when they sat immobile for Zealy's camera, and when the Swiss scientist incorporated the daguerreotyped black bodies into his theory of human difference. They simultaneously implicate the temporal reality of the twenty-first-century viewer, who realizes through his/her experience of looking at the daguerreotypes that race has a long history from 
which we (like Zealy's sitters) cannot easily escape. This argument is conversant with Shawn Smith's reading of Washington's portrait of John Brown, but seems to emphasize potential opportunities over problems of interpretation. That we know where Delia and her fellow sitters once stood, and where they would come to stand in the history of race science, provides us with a deeper understanding of how we see black bodies today and continue to invest in their stillness. Young's selection of three sets of photographs from different moments in African American history further anticipates Leigh Raiford's reading of the shadow archive. While Raiford proposed incorporating family and other positive images of black vernacular life into our conception of "lynching photography," Young constructs a photographic archive around notions of immobility. His discussion of Roberts's studio photographs in these terms and in relation to the Agassiz daguerreotypes is particularly successful. We see in these portraits from the 1920s, "working-class men and women who sought to perform and render static in a photographic image their idealized selves" through their refined dress, props, and pose (56). That such self-representation was possible two generations after Zealy's sitters, and in the same town that they were daguerreotyped, illustrates the influential premise of Reflections in Black: the camera became the primary instrument through which African Americans could refute popular images of blackness and create a reality (and history) of their own.

Young nevertheless distinguishes his approach to the Agassiz daguerreotypes from that of Willis, Carla Williams, Mandy Reid, and others by admitting that the five undressed men in the series "most intrigue me" - not Delia. They, too, are objectified, exoticized, and indeed eroticized, calling to mind for Young the "contemporary photographs of Robert Mapplethorpe, Thierry Le Goues, and Lyle Ashton Harris." He argues further that encountering the daguerreotype of a fully nude slave named Jem (seen from behind) "creates an ambivalence in the spectator that resembles that experienced by art critic Kobena Mercer upon encountering Mapplethorpe's photographs of black male nudes" (38). In his much-anthologized essay, "Skin Head Sex Thing" (1991), Mercer outlined a reading of Mapplethorpe's photographs as both objectifying the black male nude and embodying a positive identification between artist and model. Such ambivalence, he explained, stemmed from his knowledge of specific contexts informing Mapplethorpe's work, including the artist's homosexuality, his engagement with an urban gay male culture, the emergence of new aesthetic practices among black lesbian and gay artists in the 1980s, and so on. Young does not provide his readers with an analogous "context" for Agassiz (or Zealy) that would enable us to discern ambivalence in his daguerreotypes of naked black male bodies. In her essay in Pictures and Progress, however, Suzanne Schneider aims to do precisely that.

Schneider captures her reader's attention with a provocative question: Was Agassiz an ethnographer or a pornographer? Her response is equally striking. If the daguerreotypes were intended to support the ethnographer's theory that blacks and whites resulted from separate creations, then they failed miserably; 
no white bodies were photographed for comparison, the physiognomic features of the daguerreotyped slaves were not measured, and the images of naked breasts and backsides provided no valuable information about racial difference at the time. These absences lead Schneider to read Zealy's pictures as "America's first scientifically sanctioned black nudie shots" (223). To support her interpretation of the daguerreotypes as primarily sexual and erotic studies, she turns to Agassiz's biography, noting his fondness for homosocial experiences in his professional and personal life, which included a "socially transgressive and class-crossing love for his male secretary" (237). Schneider takes her point further by proposing that Agassiz sought a secure and prominent place in American racial science precisely because it would counteract the stigmatization of his "sexual proclivities" and provide him with a legitimate position from which to claim "white male dominance" $(230,233)$. This is certainly a provocative reading, but Schneider finds it necessary, given what she sees as contemporary scholars' blindness to the "hardly innocent" sexual content of the daguerreotypes and to their black male subjects in general (233). The solution to this problem, she proposes, is greater self-consciousness of the pleasures that contemporary scholars derive from their encounters with the "pornographic excesses" of the photographs (236). We must, she asserts, become more comfortable seeing ourselves in the pictures - a gesture that is encouraged by the reflective surface of the photograph, as Young notes in Embodying Black Experience. What Schneider discourages, however, are critics' assertions of mastery over the subjects, however noble or well-meaning their motivations. Too often, she observes, scholars can begin to imagine that they can "really see into the deepest recesses of these black slaves" souls" and "share the innermost secrets of these men and women" with their readers (234-35). In composing the thoughts and feelings of Zealy's sitters, as if they were communicated to her by telepathy, Molly Rogers would be treading on the dangerous critical ground that Schneider identifies - were it not for Rogers' insistence that hers is (at least in part) a work of fiction.

The innovative approaches to the Agassiz daguerreotypes considered above speak to important points of similarity and difference in current studies of early African American photography. Remarkably, however, those studies acknowledge little direct conservation among them. Pictures and Progress does not make reference to Embodying Black Experience, while Delia's Tears is cited only briefly in a footnote in Schneider's essay. The Camera and the Press, published almost simultaneously with Pictures and Progress, mentions Shawn Smith's 1999 book (American Archives) but neither Young nor Rogers. This can be explained in part by the vagaries of academic publishing (Wallace and Smith's volume has been in "progress" since 2006, when it germinated from a conference at Duke University). We must also acknowledge that histories of American photography and race are being written today across the disciplines, from literary and American studies to art history and performance studies, and even within the genre of fiction; and these fields of study have yet to become fully engaged in multi-directional conversations. Dinius, Rogers, Young, and the contributors 


\section{Tanya Sheehan}

to Pictures and Progress nevertheless share a debt to a small group of pioneers in African American photographic studies along with a commitment to rethinking the field in the twenty-first century. No longer confined to who, what, and where, their questions are now tackling the murky and contested critical space of how, why, and so what. They look to the past, digging deeply and creatively in historical archives, as well as to our present and future. This last point is leading scholars to examine with new eyes their own political assumptions, biases, and stakes - to see their own writing, that is, as a reflective surface.

\section{Works Cited}

Langford, Martha. Suspended Conversations: The Afterlife of Memory in Photographic Albums. Montreal: McGill-Queen's University Press, 2001.

Mavor, Carol. "Black and Blue: The Shadows of Camera Lucida." In Photography Degree Zero: Reflections on Roland Barthes's Camera Lucida, edited by Geoffrey Batchen. Cambridge: The MIT Press, 2009, 211-41.

Mercer, Kobena. "Skin Head Sex Thing: Racial Difference and the Homoerotic Imaginary." In How Do I Look? Queer Film and Video, edited by Bad Object Choices. Seattle: Bay Press, 1991, 169-222.

Olin, Margaret. “Touching Photographs: Roland Barthes's ‘Mistaken' Identification," Representations 80 (Fall 2002): 99-118.

Shumard, Ann. A Durable Memento: Portraits by Augustus Washington, African American Daguerreotypist. Washington, DC: National Portrait Gallery, 1999.

Smith, Shawn Michelle. American Archives: Gender, Race, and Class in Visual Culture. Princeton: Princeton University Press, 1999. . "Race and Reproduction in Camera Lucida." In Photography: Theoretical Snapshots, edited by Jonathan Long, Andrea Noble, and Edward Welch. London: Routledge, 2009, 98-111.

Wallis, Brian and Deborah Willis. African American Vernacular Photography: Selections from the Daniel Cowin Collection. New York: International Center of Photography, 2005.

Willis, Deborah. Reflections in Black: A History of Black Photographers, 18401999. New York: W.W. Norton \& Company, Inc., 2000. 


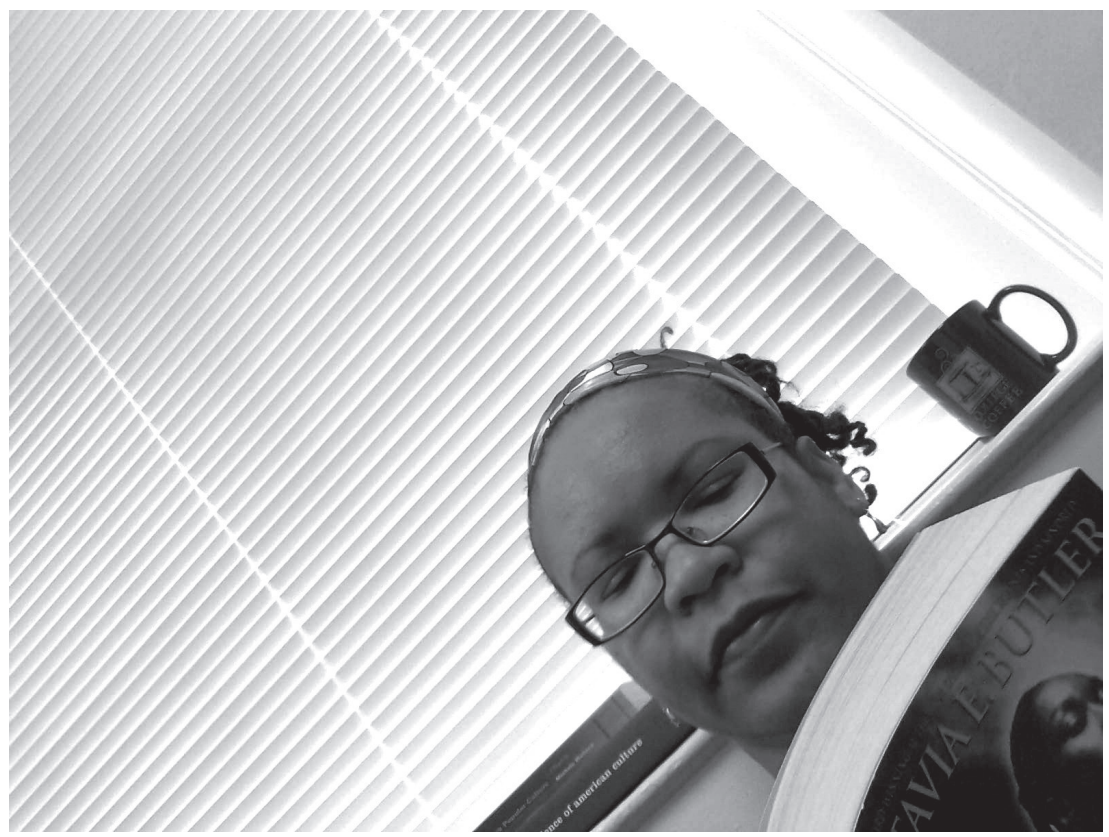

$A M S J$ editorial board member Crystal Anderson

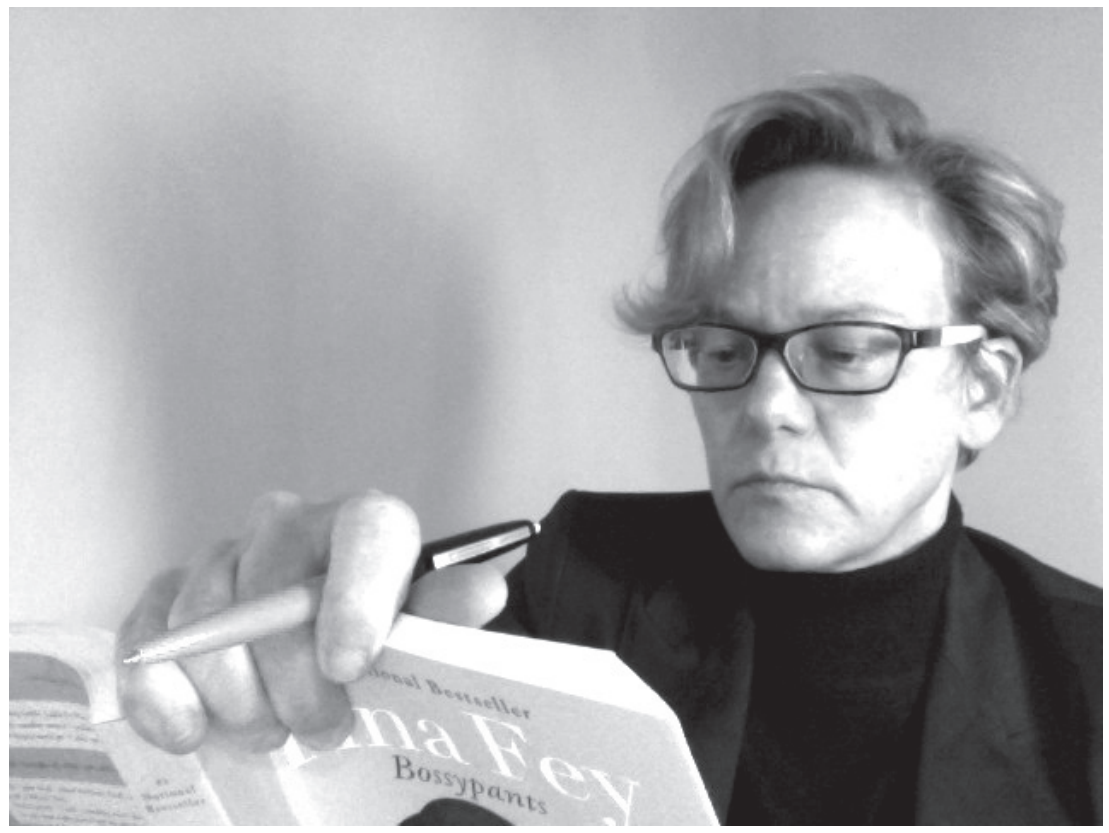

AMSJ editorial board member Carol Mason 
